RESEARCH PAPER RP1281

Part of Journal of Research of the National Bureau of Standards, Volume 24, March 1940

\title{
DIELECTRIC CONSTANT, POWER FACTOR, AND RESISTIVITY OF MARBLE
}

\author{
By Arnold H. Scott
}

ABSTRACT

The dielectric constant, power factor, and resistivity of marble from Vermont, Alabama, and Georgia were determined when the marble was dry and after it had been stored for over a month in an atmosphere having a relative humidity of 85 percent. The effect of frequency on the dielectric constant and power factor was also studied. The results are presented in the form of tables. It was found that the electrical properties of marble may vary widely but that the colored marbles have higher dielectric constants and power factors than the white marbles.

\section{CONTENTS}

I. Introduction

II. Description and preparation of specimens $\ldots \ldots 235$

III. Description of electrical measurements

IV. Results

V. Results of previous observers

VI. Conclusions

\section{INTRODUCTION}

Data on the electrical properties of marble are meager. Such data as are published vary widely. To gain more information regarding the electrical properties of marble, measurements of dielectric constant, power factor, and resistivity were made on specimens which were available from quarries in Vermont, Alabama, and Georgia. The effects of moisture and frequency on these electrical properties were studied.

\section{DESCRIPTION AND PREPARATION OF SPECIMENS}

The specimens were disks of marble about $7 \mathrm{~mm}$ thick and $15 \mathrm{~cm}$ in diameter, cut from slabs which had been carefully selected as to uniformity of appearance and coloring. The surfaces of these slabs had been carefully ground and polished.

Three varieties of marble were obtained from Vermont. These were designated as "White Vermont," "Blue Vermont," and "Jetmar." The White Vermont specimens were pure white. The Blue Vermont specimens were blue gray with darker patches or streaks giving a mottled, or clouded, appearance. The Jetmar specimens were specimens of blue-gray marble which had been impregnated with a bituminous material to give it a uniform black color. 
The marble obtained from Alabama consisted of two varieties, which were designated "White Alabama" and "Clouded Alabama." The White Alabama specimens were pure white, while the Clouded Alabama specimens were white with bluish areas or streaks, which gave them a clouded appearance.

The marble obtained from Georgia was all of one kind. These specimens had a bluish-gray color and the grain of them was much larger than the grain of the Vermont and Alabama marbles.

Electrical measurements were made under two conditions of moisture content. After the specimens had been cut to the proper size, they were dried for 24 hours in an oven at $150^{\circ} \mathrm{C}$ and then kept in a desiccator until electrical measurements were made. Following these measurements, some of the specimens were put in the humidity chamber, in which the relative humidity was maintained at 85 percent. After a little more than a month in this chamber, the specimens were again measured.

Mercury electrodes were used for the resistivity measurements and tinfoil electrodes for the dielectric-constant and power-factor measurements. The mercury electrodes were applied as described by Curtis. ${ }^{1}$ The tinfoil electrodes were applied with a thin coat of petrolatum. They were rolled down with a narrow roller until no further mark could be made on the foil with the roller. The tinfoil was applied over the entire area of each flat surface; then one of the electrodes was cut with a circular cutter and a narrow ring removed, leaving a circular electrode with a guard electrode surrounding it. The diameter of the center, or guarded, electrode was $11.0 \mathrm{~cm}$, and the width of the gap between the guarded electrode and the guard ring was about $0.05 \mathrm{~cm}$.

\section{DESCRIPTION OF ELECTRICAL MEASUREMENTS}

The volume resistance of each specimen was measured by the directdeflection method described in a former paper. ${ }^{2}$ For these measurements the specimens were at room temperature.

The dielectric-constant and power-factor measurements were made as described in another paper. ${ }^{3}$ The specimens were mounted in a metal box which was part of a constant-humidity chamber and which was kept at a temperature of $25^{\circ} \mathrm{C}$. This metal box served as an electrostatic shield and was so designed that all stray capacitance was removed from the measuring circuit. The capacitance and power factor were measured with a conjugate Schering bridge with an earthing arm. ${ }^{4}$ A vibration galvanometer was used as detector at $100 \mathrm{c} / \mathrm{s}$ in connection with a one-stage amplifier. At $1,000 \mathrm{c} / \mathrm{s}$ the vibration galvanometer was replaced by a telephone receiver. For frequencies above $1,000 \mathrm{c} / \mathrm{s}$ an amplifier was used which had an oscillator built into it so that a 1,000-cycle beat note vras produced. A telephone receiver was then used to detect the beat nute.

\footnotetext{
1 Harvey L. Curtis, Bul. BS 11, 359 (1914) S234.

A. H. Scott, A. T. MePherson, and Harvey L. Curtis, BS J. Research 11, 173 (1933) RP585.

8 Arnold H. Scott and Harvey L. Curtis, J. Research NBS 22, 747 (1939) RP1217.

4 This bridge is described in a tentative method of the ASTM entitled "Tentative methods of testing electrical insulating material for power factor and dielectric constant, D 150-36T." See Proc. Am. Soc. Testing Materials 36, pt. 1, 955 (1936).
} 


\section{RESULTS}

The results of the different measurements are given in tables 1 to 4 . The maximum, minimum, and mean values are given for each variety of specimens and for each set of given conditions. The conditions which were varied were the amount of absorbed moisture and the frequency of the alternating current used in measuring the dielectric constant and power factor.

TABLE 1.-Dielectric constant of marble at 1,000 cycles per second

\begin{tabular}{|c|c|c|c|c|c|c|c|c|c|}
\hline \multirow[b]{2}{*}{ Variety of marble } & \multicolumn{4}{|c|}{ Dry } & \multicolumn{5}{|c|}{$\begin{array}{c}\text { After } 30 \text { days at } 85 \text {-percent relative } \\
\text { humidity }\end{array}$} \\
\hline & $\begin{array}{l}\text { Num- } \\
\text { ber of } \\
\text { speci- } \\
\text { mens }\end{array}$ & $\begin{array}{l}\text { Maxi- } \\
\text { mum }\end{array}$ & $\begin{array}{l}\text { Mini- } \\
\text { mum }\end{array}$ & Mean & $\begin{array}{l}\text { Num- } \\
\text { ber of } \\
\text { speci- } \\
\text { mens }\end{array}$ & $\begin{array}{l}\text { Maxi- } \\
\text { mum }\end{array}$ & $\begin{array}{l}\text { Mini- } \\
\text { mum }\end{array}$ & Mean & $\begin{array}{l}\text { Percent- } \\
\text { age of } \\
\text { increase }\end{array}$ \\
\hline $\begin{array}{l}\text { White Vermont } \\
\text { White Alabama } \\
\text { Blue Vermont. } \\
\text { Clouded Alabama } \\
\text { Jetmar }\end{array}$ & $\begin{array}{l}4 \\
4 \\
8 \\
8 \\
4 \\
8\end{array}$ & $\begin{array}{r}8.64 \\
8.57 \\
8.80 \\
9.05 \\
8.40 \\
10.55\end{array}$ & $\begin{array}{r}8.55 \\
8.55 \\
8.62 \\
8.66 \\
8.34 \\
10.03\end{array}$ & $\begin{array}{r}8.58 \\
8.56 \\
8.72 \\
8.83 \\
8.38 \\
10.32\end{array}$ & $\begin{array}{l}3 \\
4 \\
4 \\
4 \\
4 \\
3\end{array}$ & $\begin{array}{r}9.41 \\
8.71 \\
9.78 \\
11.36 \\
8.60 \\
14.08\end{array}$ & $\begin{array}{r}9.04 \\
8.60 \\
8.94 \\
9.93 \\
8.42 \\
13.22\end{array}$ & $\begin{array}{r}9.21 \\
8.67 \\
9.31 \\
10.41 \\
8.49 \\
13.69\end{array}$ & $\begin{array}{r}7 \\
1 \\
6 \\
17 \\
1 \\
35\end{array}$ \\
\hline
\end{tabular}

TABLE 2.-Power factor of marble at 1,000 cycles per second

\begin{tabular}{|c|c|c|c|c|c|c|c|c|c|}
\hline \multirow[b]{2}{*}{ Variety of marble } & \multicolumn{4}{|c|}{ Dry } & \multicolumn{4}{|c|}{$\begin{array}{l}\text { After } 30 \text { days at } 85 \text {-percent } \\
\text { relative humidity }\end{array}$} & \multirow{2}{*}{$\begin{array}{l}\text { Ratio, } \\
\text { moist/dry }\end{array}$} \\
\hline & $\begin{array}{l}\text { Num- } \\
\text { ber of } \\
\text { speci- } \\
\text { mens }\end{array}$ & $\underset{\times 10^{3}}{\text { Maxi- }}$ & $\begin{array}{l}\text { Mini- } \\
\text { mum } \\
\times 10^{3}\end{array}$ & $\begin{array}{c}\text { Mean } \\
\times 10^{3}\end{array}$ & $\begin{array}{l}\text { Num- } \\
\text { ber of } \\
\text { speci- } \\
\text { mens }\end{array}$ & $\begin{array}{l}\text { Maxi- } \\
\text { mum } \\
\times 10^{3}\end{array}$ & $\begin{array}{l}\text { Mini- } \\
\text { mum } \\
\times 10^{3}\end{array}$ & $\underset{\times 10^{3}}{\text { Mean }}$ & \\
\hline White Ve & 4 & 1.2 & 1. 0 . & 1.1 & 3 & 40 & 25 & 33 & 30 \\
\hline White Alabama & 4 & 5. 6 & 2.5 & 3. & 3 & 14 & 3 & 9 & 3 \\
\hline Blue Vermont_. & 8 & 8.3 & 3.0 & 4. 7 & 4 & 53 & 19 & 32 & 7 \\
\hline Clouded Alabama... & 8 & 14.0 & 3.5 & 8.6 & 4 & 310 & 160 & 230 & 27 \\
\hline Jetmar & 4 & 2.7 & 2.3 & 2.5 & 4 & 13 & 3 & 5 & 2 \\
\hline Georgia & 8 & 31.0 & 11.0 & 18.0 & 3 & 230 & 170 & 200 & 11 \\
\hline
\end{tabular}

TABLE 3.-Volume resistivity of marble

\begin{tabular}{|c|c|c|c|c|c|c|c|c|c|}
\hline \multirow[b]{2}{*}{ Variety of marble } & \multicolumn{4}{|c|}{ Dry } & \multicolumn{4}{|c|}{$\begin{array}{c}\text { After } 30 \text { days at } 85 \text {-percent relative } \\
\text { humidity }\end{array}$} & \multirow{2}{*}{ 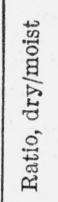 } \\
\hline & 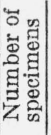 & 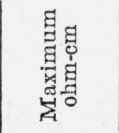 & 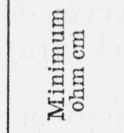 & 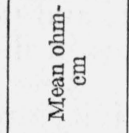 & 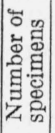 & 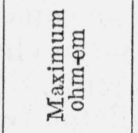 & 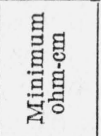 & 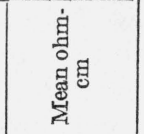 & \\
\hline $\begin{array}{l}\text { White Vermont } \\
\text { White Alabama } \\
\text { Blue Vermont..... } \\
\text { Clouded Alabama.. } \\
\text { Jetmar } \\
\text { Georgia. }\end{array}$ & $\begin{array}{l}4 \\
4 \\
6 \\
8 \\
4 \\
8\end{array}$ & $\begin{array}{l}24 \times 10^{12} \\
340 \\
1,800 \\
300 \\
4,700 \\
1,200\end{array}$ & $\begin{array}{c}21 \times 10^{12} \\
20 \\
50 \\
20 \\
2,600 \\
50\end{array}$ & \begin{tabular}{|c|}
$22 \times 10^{12}$ \\
180 \\
630 \\
140 \\
3,900 \\
380
\end{tabular} & $\begin{array}{l}2 \\
4 \\
3 \\
8 \\
4 \\
8\end{array}$ & $\begin{array}{c}1.3 \times 10^{12} \\
0.054 \\
.18 \\
.10 \\
1,800.64\end{array}$ & $\begin{array}{l}1.2 \times 10^{12} \\
0.005 \\
.04 \\
.005 \\
9.007\end{array}$ & $\mid \begin{array}{c}1.3 \times 10^{12} \\
0.024 \\
.11 \\
.031 \\
1,000 \\
.20\end{array}$ & $\begin{array}{r}20 \\
8,000 \\
6,000 \\
5,000 \\
4,000\end{array}$ \\
\hline
\end{tabular}


TABLE 4.-Change of dielectric constant and power factor of dry marble with frequency

\begin{tabular}{|c|c|c|c|c|}
\hline \multirow{3}{*}{ Frequency } & \multicolumn{4}{|c|}{ Variety of marble } \\
\hline & \multicolumn{2}{|c|}{ White Vermont } & \multicolumn{2}{|c|}{ Blue Vermont } \\
\hline & $\begin{array}{l}\text { Dielectric } \\
\text { constant }\end{array}$ & Power factor & $\begin{array}{l}\text { Dielectric } \\
\text { constant }\end{array}$ & Power factor \\
\hline $\begin{array}{l}c / s \\
100 \\
1000 \\
1000000 \\
100,000\end{array}$ & $\begin{array}{l}8.60 \\
8.58 \\
8.57 \\
8.55 \\
8.53\end{array}$ & $\begin{array}{l}1.4 \times 10^{-3} \\
1.1 \\
1.7 \\
1.6 \\
1.4\end{array}$ & $\begin{array}{l}8.79 \\
8.75 \\
8.69 \\
8.65 \\
8.63\end{array}$ & $\begin{array}{l}3.1 \times 10^{-3} \\
4.2 \\
5.0 \\
4.8\end{array}$ \\
\hline
\end{tabular}

The values of the dielectric constant at $1,000 \mathrm{c} / \mathrm{s}$ are given in table 1. When measured dry, the dielectric constants of the White Vermont and White Alabama marbles may be considered as identical, since the indicated difference is less than experimental variation. However, when exposed to a relative humidity of 85 percent, the dielectric constant of the White Vermont marble increased more than the dielectric constant of the White Alabama marble.

The colored marbles had higher dielectric constants than the white marbles. Also, the moisture affected the dielectric constants of the colored marbles more than it did the dielectric constant of the White Alabama marble. The dielectric constants of the White Vermont and the Blue Vermont were about equally affected by moisture. On the other hand, Jetmar, which was artificially colored by impregnating with a bituminous material, actually had a lower value of dielectric constant than the white marble. Moisture affected the dielectric constant of Jetmar only slightly. This was to be expected as the bituminous material tended to make the marble moisturerepellent.

The values of the power factor at $1,000 \mathrm{c} / \mathrm{s}$ are given in table 2 . There is a large spread between extreme values, in one case the maximum being 4 times the minimum. The colored marbles have higher power factors than the white marbles, and the moisture affects the power factors of the colored marbles more than it does the power factor of the White Alabama marble. However, the moisture increased the power factor of the White Vermont marble more than it did that of any of the other marbles. In a general way, the moisture affected the dielectric constants and power factors alike, that is, those specimens having large changes in dielectric constant also had large changes in power factor.

The values of volume resistivity are giver in table 3 . The spread between the maximum and minimum values is greater than for power factor. In one case the maximum is 200 times the minimum. There is no discernible systematic relationship between the values. The resistivities of the dry specimens are four to 10,000 times the resistivities of the moist specimens. There is no apparent connection between the resistivities and the power factors.

The change of the electrical property with absorbed moisture may not be that indicated by the change in mean values. In one case the 
specimen which had a minimum value of power factor when dry had the maximum value of power factor when moist. In other cases it was the reverse.

The effect of frequency on the dielectric constant and power factor of dry marble is shown in table 4. Each of the values given is the average of measurements on four specimens. The dielectric constant decreased slightly with frequency, but there was no certain change of the power factor with frequency.

\section{RESULTS OF PREVIOUS OBSERVERS}

The values of the dielectric constant of marble obtained by other observers are given in table 5. The values given in this paper are consistent with these values. However, the work of Jaeger and of Preston and Hall indicates that the dielectric constant does not change with frequency, whereas the results of Rubens would indicate that the dielectric constant of marble increases with frequency. The present work, on the other hand, indicates that the dielectric constant decreases slightly with frequency.

The values of the resistivity of marble given by Curtis $^{5}$ were all much lower than the values given in this paper. He gave the value of $1 \times 10^{9} \mathrm{ohm}-\mathrm{cm}$ for blue Vermont marble, $5 \times 10^{9} \mathrm{ohm}-\mathrm{cm}$ for pink Tennesse marble and $1 \times 10^{11} \mathrm{ohm}-\mathrm{cm}$ for Italian marble. These values were obtained at relative humidities encountered in the laboratory (probably below 35 percent), yet they are lower than the values given in table 3 at a relative humidity of 85 percent. As two of the specimens measured by Curtis were still available in the laboratory, they were remeasured. These measurements checked the previous measurements within the experimental error.

TABLE 5.-Values of dielectric constant of marble obtained by previous observers

\begin{tabular}{|c|c|c|c|}
\hline Variety of marble & $\begin{array}{l}\text { Dielectric } \\
\text { constant }\end{array}$ & Frequency & Observer \\
\hline $\begin{array}{l}\text { Unknown } \\
\text { Do } \\
\text { Do } \\
\text { Do } \\
\text { Do } \\
\text { White } \\
\text { Gray } \\
\text { Blue }\end{array}$ & $\begin{array}{r}8.35 \\
8.35 \\
8.22 \\
8.44 \\
8.67 \\
9.3 \\
11.6 \\
9.4\end{array}$ & $\begin{array}{l}\text { "Very high", c/s } \\
250 \text { to } 10^{7} \\
3 \times 10^{7} \\
5 \times 10^{8} \\
1012 \\
8 \times 10^{4} \text { to } 1.8 \times 10^{6}-10 \\
1.8 \times 10^{6}-8 \times 10^{6} \\
1.20\end{array}$ & $\begin{array}{l}\text { Schmidt. } 1 \\
\text { Jaeger. } \\
\text { Rubens. }{ }^{3} \\
\text { Do. } .^{3} \\
\text { Do. }{ }^{3} \\
\text { Preston and Hall.4 } \\
\text { Do. } .^{4} \\
\text { Do. }\end{array}$ \\
\hline
\end{tabular}

1 W. Schmidt, Ann. Physik 11, 114 (1903).

2 R. Jaeger, Ann. Physik 53, 409 (1917).

3 H. Rubens, Sitzber. preuss. Akad. Wiss. p. 4 (1915); p. 556 (1917)

J. L. Preston and E. L. Hall, QST 9, 26 (Feb. 1925).

Kessler ${ }^{6}$ has published values of volume resistivity for American marbles which ranged from $10^{6} \mathrm{ohm}-\mathrm{cm}$ to $3.9 \times 10^{14} \mathrm{ohm}-\mathrm{cm}$. The measurements were made on specimens which had been dried in air after immersion for 48 hours in water.

$\checkmark$ Harvey L. Curtis, Bul. BS 11, 359 (1914) S234.

6 D. W. Kessler, Physical and chemical tests on the commercial marbles of the United States, Tech. Pap. BS 12(1919) Tं123. 


\section{CONCLUSIONS}

It is apparent that the electrical properties of marble may vary widely. The colored specimens had higher dielectric constants and power factors than the white specimens. The resistivity varied so that general conclusions could not be drawn regarding it. Absorbed moisture increased the dielectric constant and power factor and decreased the resistivity. The variation between specimens was much greater for the moist specimens than for the dry. Because of the large variations between the values for different specimens and between different varieties, it is not possible to give definite values of the electrical properties of marble.

WASHINGton, January 8, 1940. 